\title{
Statement of Work for Analytical Services Provided to Westinghouse Hanford Company by the Pacific Northwest National Laboratory Analytical Chemistry Laboratory
}

\author{
J. K. Perry
}

Date Published

May 1996

Prepared for the U.S. Department of Energy Office of Environmental Restoration and Waste Management

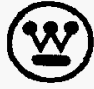


LECAL DISCLAMMER

This report wes prepared as an account of work sponsored by an agency of the United States Government. Neither the United States Government nor any agency thereof, nor any of their employees, nor any of their contractors, subcontractors or their employees, makes any warranty, express or implied, or assumes any legal liability or responsibility for the accuracy, completeness, or any third party's use or the results of such usa of any information, apparatus, product, or process disclosed, or represents that its use would not infringe privately owned rights. Reference herein to any specific commercial product, process, or service by trade name. trademark, menufacturer, or otherwise, does not necessarily constitute or imply its endorsement, recommendation, or favoring by the United States Government or any agency thereof or its contractors or subcontractors. The views and opinions of authors expressed herain do not necessarily state of refloct those of the United States Government or any agency thereof.

This report hes been reproduced from the best available copy. Available in paper copy and microfiche.

Available to the U.S. Department of Energy and its contractors from

Office of Scientific and Technical Information

P.O. Box 62

Oak Ridge, TN 37831

(615) $576-8401$

Available to the public from the U.S. Department of Commerce National Technical Information Service

5285 Port Royal Road

Springtield, VA 22161

(703) 487.4650

Printed in the United Stetes of Ameries

DISCLM-1.CHP (1-91) 


\section{RELEASE AUTHORIZATION}

Document Number: WHC-EP-0857-1

Statement of Work for Analytical Services Provided

Document Title: to Westinghouse Hanford Company by the Pacific

Northwest National Laboratory Analytical Chemistry Laboratory

Release Date:

$05 / 24 / 96$

This document was reviewed following the procedures described in WHC-CM-3-4 and is:

\section{APPROVED FOR PUBLIC RELEASE}

WHC Information Release Administration Specialist:
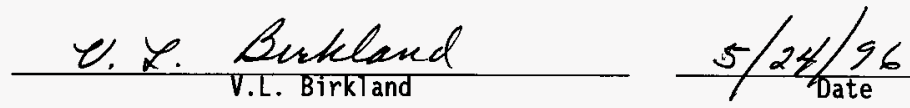
WHC-EP-0857-1

Approved by: $\frac{\mathscr{L} Q \text { gheemmed }}{\text { L.R. Greenwood, Lead Scientist, }} \frac{5 / 23 / 96}{\text { PNNL Analytical Chemistry }}$ Laboratory

T.k. Parry for $K . J_{1} k-K$ per talewein $5 / 23 / 96$

Approved by:

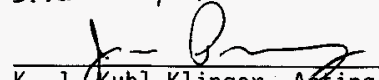

K. J. Kuh 1-K1 inger, Aéting Manager

PNNL Analytical Chemistry

Laboratory

Approved by:

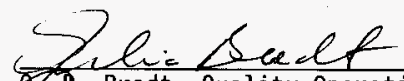

Q. Bredt, Quality Operations,

PANL Analytical Chemistry

Laboratory

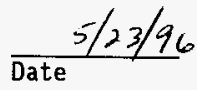

Reviewed by:

T. L. Almeida, QE Engineer,

PNNL Analytical Chemistry

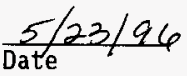

Laboratory

Approved by:

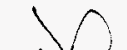

$6 \%$

D. G. Panther, Manager, 306 Facility

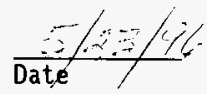

Approved by:

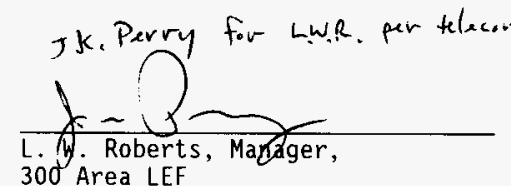

$\frac{5-23-96}{\text { Date }}$

J.K. Perry for TAD per telecom $5 / 22 / 96$
$3: 40$ in

Approved by:

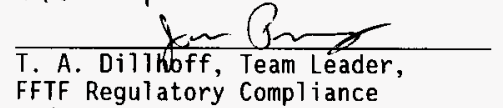

$$
\begin{aligned}
& 5 / 23 / 96 \\
& 11244 \mathrm{~m}
\end{aligned}
$$

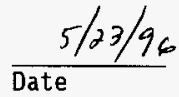

and ECO, FFTF/MASF

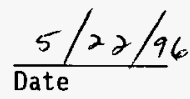




$$
\text { WHC-EP-0857-1 }
$$

Document Title: STATEMENT OF WORK FOR ANALYTICAL SERVICES PROVIDED TO WHC BY PNNL'S ANALYTICAL CHEMISTRY LABORATORY SUPPORTING RADIOACTIVE AIRBORNE EMISSIONS MEASUREMENT

Prepared by:

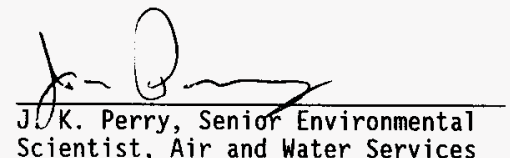

Approved by:

Approved by:

Approved by:

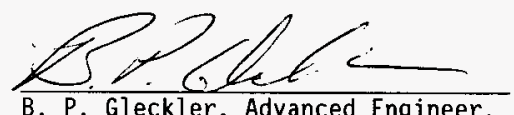

B. P. Gleckler, Advanced Engineer, Air and Water Services

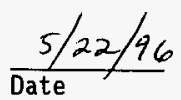

$\frac{5 / 23 / 96}{\text { Date }}$
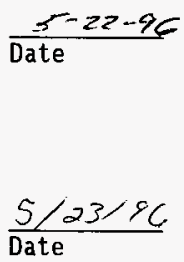

Approved by:
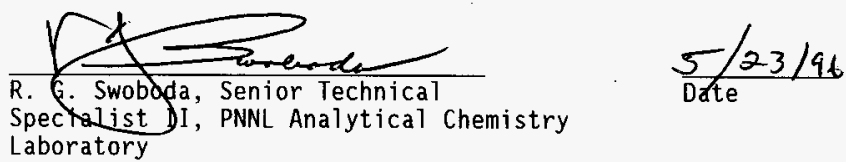
WHC-EP-0857-1

\section{TABLE OF CONTENTS}

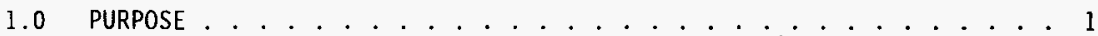

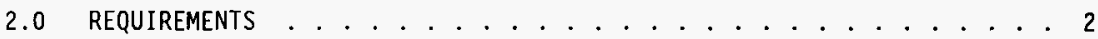

2.1 Regulatory Requirements ................ 2

2.2 Contracted Analytical Laboratory . . . . . . . . . . . 2

2.3 Variances to the sow ................. 2

3.0 REGULATORY REPORTING REQUIREMENTS ................. . . 3

3.1 Radionuclide Air Emissions Report . . . . . . . . . . . 3

3.2 Annual Environmental Releases Report ............. 3

3.3 Hanford Site Environmental Report . . . . . . . . . . . . 3

3.4 Effluent Information System/Onsite Discharge Information system .............. 3

4.0 ANALYTICAL LABORATORY SERVICES AND DATA QUALITY OBJECTIVES . . . . 4

4.1 Required Analytical and Data Handling Services ........ 4

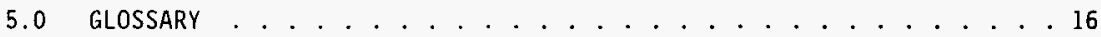

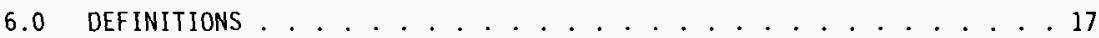


WHC-EP-0857-1

\section{LIST OF TABLES}

Table 1 Sample and Analysis Criteria for the 306 Facility . . . . . . . . . . . . . . 6

Table 2.1 Sample and Analysis Criteria

for the 340 Facility, 340-NT-EX Stack . . . . . . . . . . 7

Table 2.2 Sample and Analysis Criteria

for the 340 Facility, 340-DECON Stack . . . . . . . . . . . 8

Table 2.3 Sample and Analysis Criteria

for the 340 Facility, 340-B-BLDG Stack . . . . . . . . . 9

Table 3.1 Sample and Analysis Criteria

for the FFTF, FFTF-CB-EX Stack . . . . . . . . . . 10

Table 3.2 Sample and Analysis Criteria

for the FFTF, FFTF-RE-SB Stack . . . . . . . . . . . . . 11

Table 3.3 Sample and Analysis Criteria

for the FFTF, FFTF-HT-TR Stack ............. 12

Table 4.1 Sample and Analysis Criteria

for the 437 Maintenance and Storage Facility

437-MN\&ST Stack .................... 13

Table 4.2 Sample and Analysis Criteria

for the 437 Maintenance and Storage Facility

437-1-61 Stack................... . . 14

Table 5 ERS Reporting Parameters ................. 15 
WHC-EP-0857-1

\subsection{PURPOSE}

The purpose of this Statement of Work (SOW) is to establish laboratory analytical criteria and requirements associated with radioactive airborne emissions measurements. The criteria and requirements in this document apply to airborne emissions measurement activities funded by WHC managed facilities in the 300 and 400 Areas. 


$$
\text { WHC-EP-0857-1 }
$$

\subsection{REQUIREMENTS}

\subsection{Regulatory Requirements}

In accordance with Clean Air Act requirements (40 CFR 61.93 and WAC 246247), owners and operators of radioactive airborne emissions units are required to implement a quality assurance program for radioactive airborne emissions measurement activities. In accordance with these requirements, WHC has developed a Quality Assurance Project Plan (WHC-EP-0528-2) which documents the quality assurance activities associated with data collection and reporting of radioactive airborne emissions measurements. Included in WHC-EP-0528-2 are requirements for the following:

* Air and Water Services (AWS) shall prepare a SOW for WHC's radioactive airborne emissions measurement program

* AWS shall identify analytical criteria and detection limits for laboratory radioanalytical services.

This document fulfills the above stated requirements.

\subsection{Contracted Analytical Laboratory}

Analytical services for the radioactive airborne emissions measurement program for WHC managed facilities in the 300 and 400 Areas are to be provided by Pacific Northwest National Laboratory's (PNNL's) Analytical Chemistry. Laboratory.

\subsection{Variances to the SOW}

Variances to this SOW must be documented by PNNL and approved or acknowledged by AWS. 
WHC-EP-0857-1

\subsection{REGULATORY REPORTING REQUIRENENTS}

The sample data, resulting from the radioactive airborne emissions measurement program for WHC managed facilities in the 300 and 400 Areas, supports a number of regulatory reporting requirements. A description of the required reports which this program supports is provided below.

\subsection{Radionuclide Air Emissions Report}

This report (prepared by AWS) documents Hanford Site radioactive airborne emissions measurements results. Within this report, emissions measurements are used to estimate the annual effective dose equivalent (EDE) received by the hypothetical off-site highest receptor. This report complies with the reporting requirements of Washington Administrative Code (WAC) 246-247, "Radiation Protection-Air Emissions," and the Code of Federal Regulations (CFR) Title 40, Protection of the Environment, Part 61, "National Emissions Standards for Hazardous Air Pollutants," Subpart H, "National Emission Standards for Emissions of Radionuclides Other Than Radon From Department of Energy Facilities."

\subsection{Annual Environmental Releases Report}

This annual report (prepared by AWS) fulfills effluent discharge reporting requirements of DOE Order 5400.1 and DOE Order 5484.1. This report summarizes the degree to which emissions of regulated substances (i.e radioactive airborne emissions) from Hanford Site facilities comply with applicable regulatory limits.

\subsection{Hanford Site Environmental Report}

This report is compiled and published annually by PNNL for RL to comply with the requirements of DOE Order 5400.1.

\subsection{Effluent Information System/Onsite Discharge Information System}

This report is transmitted electronically (by AWS) to Idaho National Engineering Laboratory (INEL) in Idaho Falls, Idaho for inclusion in the Department of Energy's (DOE's) Effluent Information System/Onsite Discharge Information System (EIS/ODIS) database. This report complies with the requirements of DOE Order 5484.1 and DOE Order 5400.1. 
WHC-EP-0857-1

\subsection{ANALYTICAL LABORATORY SERVICES AND DATA QUALITY OBJECTIVES}

\subsection{Required Analytical and Data Handling Services}

PNNL's Analytical Chemistry Laboratory shall provide the following analytical and data handling services.

4.1.1 Analytical services shall meet the analytical requirements listed in Tables $1-4$.

4.1.2 PNNL shall implement a Quality Assurance (QA) Program which meets the applicable requirements of 40 CFR Part 61, Appendix B, Method 114, Section 4.0.

4.1.3 Quality control test results and laboratory intercomparison scores shall be provided to WHC upon request; the tests shall include accuracy, precision, and background.

4.1.4 PNNL shall participate in the DOE-Inter-Laboratory Quality Assurance Program coordinated by the DOE Environmental Measurements Laboratory, NY, NY, as applicable for requested analyses.

4.1.5 Upon request, WHC shall be permitted to review and approve the QA program.

4.1.6 Weekly particulate samples for the 340 Tank Vent Stack (340-NT-EX) shall be saved and composited for quarterly specific radionuclide analyses. The composited samples shall be analyzed for Pu-239,240, Pu-238, Pu-242, Am241, and Cs-137 in accordance with 40 CFR Part 61, Appendix B, Method 114 (see Table 3.1).

Note: Historical data indicates that sample activity levels are typically insufficient to allow for the detection of specific radionuclides. Therefore, as a cost savings measure, gross alpha/beta measurements shall be performed on composite samples prior to performing specific analyses. If insufficient activity levels are present to allow for possible detection of the specified radionuclides, specific radionuclide analyses shall not be not performed. Conversely, specific radionuclide analyses shall be performed when gross alpha/beta activity levels are sufficient to allow for possible detection of specific radionuclides.

* The above note is not applicable for GEA specific radionuclide analyses. 


\section{WHC-EP-0857-1}

4.1.7 PNNL analytical data shall meet a minimum completeness criteria of 90 percent ( $90 \%$ of samples analyses for each stack shall meet the minimum requirements established in this document).

4.1.8 Analytical results shall be expressed in the units shown for the respective minimum detectable concentrations (MDC) in Tables 1-4.

4.1.9 PNNL shall transmit sample analysis results to AWS in an electronic format which can be downloaded into the Environmental Release Summary (ERS) Database. Table 5 lists parameters for reporting data via the ERS Database.

4.1.10 All raw data and analytical results shall be retained as quality assurance documents for a minimum of 5 years, as specified by 40 CFR 61 , Subpart H and WAC 246-247 requirements. Upon request, WHC AWS shall be provided with access to the raw data and analytical results.

4.1.11 In the event that alpha/beta activity is detected at MDC levels or greater (see Tables 1-4), PNNL shall contact AWS for guidance on performing follow-up analyses. 
WHC-EP-0857-1

Table 1

Sample and Analysis Criteria

for the 306 Facility

\begin{tabular}{|c|c|c|c|c|c|c|c|}
\hline \multicolumn{8}{|c|}{306 FACILITY, 306U-LAB Stack } \\
\hline \multicolumn{8}{|c|}{ SAMPLE AND ANALYSIS CRITERIA } \\
\hline Sample Size & $\begin{array}{l}\text { Type of } \\
\text { Analys is }\end{array}$ & Precision & Accuracy ${ }^{b}$ & $\begin{array}{l}\text { Samples /yr } \\
\text { (del ivery, } \\
\text { frequency) }\end{array}$ & $\begin{array}{l}\mathrm{MDC}^{\mathrm{c}} \\
\mathrm{CO} / \mathrm{CC}\end{array}$ & $\begin{array}{l}\text { TT, } \\
\text { days }\end{array}$ & $\begin{array}{c}\text { Unit } \\
\text { Price, } \\
5\end{array}$ \\
\hline $\begin{array}{l}\text { nominal } \\
2 \text { cfm for } \\
\text { period of } \\
\text { collection, } \\
\text { unless } \\
\text { otherwise } \\
\text { indicated }\end{array}$ & $\begin{array}{c}\text { gross } \alpha \\
\text { and } \\
\text { gross } B\end{array}$ & $<20 \%$ & $\begin{array}{c}\text { See } \\
\text { Footnote b }\end{array}$ & $\stackrel{4}{(1 / q r t r)}$ & $\begin{array}{l}2.0 \mathrm{E}-15 \\
\text { and } \\
1.9 \mathrm{E}-14\end{array}$ & 14 & 65 \\
\hline
\end{tabular}

a HASQAP (DOE/RL-94-55), Table 11-1 states that duplicate analyses should have < $20 \%$ relative percent difference when the result is $>5$ times the minimum detectable activity.

b Performance evaluation sample/analys is results should meet the minimum acceptability scores specified by the evaluation study.

c MDCs shall be as low as reasanably attainable, but shall not exceed the values specified in the table.

d It is possible that less than stated number of samples will be del ivered for analysis. 
WHC-EP-0857-1

Table 2.1

Sample and Analysis Criteria

for the 340 Facility

\begin{tabular}{|c|c|c|c|c|c|c|c|}
\hline \multicolumn{8}{|c|}{340 FACILITY, 340-NT-EX Stack } \\
\hline \multicolumn{8}{|c|}{ SANPLE AND ANALYSIS CRITERIA } \\
\hline Sample Size & $\begin{array}{l}\text { Type of } \\
\text { Analysis }\end{array}$ & Precision ${ }^{a}$ & Accuracy ${ }^{b}$ & $\begin{array}{l}\text { Samples/yr } \\
\text { (del lvery } \\
\text { frequency) }\end{array}$ & $\begin{array}{l}\mathrm{MDC}^{\mathrm{C}} \\
\mu \mathrm{Cl} / \mathrm{Cc}\end{array}$ & $\begin{array}{l}\text { TT, } \\
\text { days }\end{array}$ & $\begin{array}{l}\text { Unit } \\
\text { Price, } \\
\quad \$\end{array}$ \\
\hline \multirow{7}{*}{$\begin{array}{l}\text { nominal } 3.1 \\
\text { cfm for } \\
\text { period of } \\
\text { collection, } \\
\text { unless } \\
\text { otherwise } \\
\text { indicated }\end{array}$} & $\begin{array}{c}\text { gross } \alpha \\
\text { and } \\
\text { gross } B \\
\end{array}$ & \multirow[t]{7}{*}{$<20 \%$} & \multirow[t]{7}{*}{$\begin{array}{c}\text { See } \\
\text { Footnote b }\end{array}$} & $\left(1 / 2^{26}\right.$ wks $)$ & $\begin{array}{l}2.0 \mathrm{E}-15 \\
\text { and } \\
1.9 \mathrm{E}-14\end{array}$ & 14 & 65 \\
\hline & ${ }^{131} \mathrm{I}$ & & & $\stackrel{4}{(1 / \operatorname{artr})}$ & $2.1 \mathrm{E}-13$ & 14 & 35 \\
\hline & ${ }^{238} \mathrm{Pu}^{\mathrm{d}}$ & & & $\begin{array}{c}4 \\
\text { (1/grtr) }\end{array}$ & $2.1 \mathrm{E}-15$ & 60 & 175 \\
\hline & ${ }^{242} \mathrm{Pu}^{d}$ & & & $\begin{array}{c}4 \\
(1 / \operatorname{grtr})\end{array}$ & $2.0 \mathrm{E}-15$ & 60 & 175 \\
\hline & ${ }^{241} \mathrm{Am}^{\mathrm{d}}$ & & & $\stackrel{4}{(1 / q r t r)}$ & $1.9 E-15$ & 60 & 175 \\
\hline & $\begin{array}{l}\text { gamma } \\
\text { spec } \\
\left({ }^{137} \mathrm{Cs}\right)^{d}\end{array}$ & & & $\begin{array}{c}4 \\
(1 / \operatorname{qrtr})\end{array}$ & $1.9 \mathrm{E}-14$ & 60 & 35 \\
\hline & $239,240 \mathrm{Pu}^{d}$ & & & $\begin{array}{c}4 \\
(1 / q r t r)\end{array}$ & $2.0 \mathrm{E}-15$ & 60 & 175 \\
\hline
\end{tabular}

a HASOAP (DOE/RL-94-55), Table 11-1 states that duplicate analyses should have < $20 \%$ relative percent difference when the result is > 5 times the minimum detectable activity.

b Performance evaluation sample/analysis results should meet the minimum acceptability scores specified by the evaluation study.

c MDCs shall be as low as reasonably attainable, but shall not exceed the values specified in the tabie.

d Sample analyses for the specified radionuclide shall be performed quarterly on a composite of the particulate samples collected during each quarter of the calendar year.

Note: Historical data indicates that sample activity levels are typically insufficient to allow for the detection of specific radionuclides. Therefore, as a cost savings measure, gross alpha/beta measurements shall be performed on composite samples prior to performing specific analyses. If insufficient activity levels are present to allow for possible detection of the specified

radionuclides, specific radionuclide analyses shall not be not performed. Conversely, specific radionuclide analyses shall be performed when gross alpha/beta activity levels are sufficient to allow for possible detection of specific radionuclides.

* The above note is not applicable for GEA specific radionuclide analyses. 
WHC-EP-0857-1

Table 2.2

Sample and Analysis Criteria

for the 340 Facility

\begin{tabular}{|c|c|c|c|c|c|c|c|}
\hline \multicolumn{8}{|c|}{340 FACILITY, 340-DECON Stack } \\
\hline \multicolumn{8}{|c|}{ SAMPLE AND ANALYSIS CRITERIA } \\
\hline Sample Size & $\begin{array}{l}\text { Type of } \\
\text { Analys is } \\
\end{array}$ & Precision & Accuracy ${ }^{b}$ & $\begin{array}{l}\text { Samples/yr } \\
\text { (del ivery } \\
\text { frequency) }\end{array}$ & $\begin{array}{l}M O C^{C} \\
\mu \mathrm{Ci} / \mathrm{CC}\end{array}$ & $\begin{array}{l}\text { TT, } \\
\text { days }\end{array}$ & $\begin{array}{r}\text { Unit } \\
\text { Price, } \\
\quad \$\end{array}$ \\
\hline $\begin{array}{l}\text { nominal } \\
2 \mathrm{cfm} \text { for } \\
\text { period of } \\
\text { collection, } \\
\text { unless } \\
\text { otherwise } \\
\text { indicated }\end{array}$ & $\begin{array}{l}\operatorname{gross} \alpha \\
\text { and } \\
\text { gross } B\end{array}$ & $<20 \%$ & $\begin{array}{c}\text { See } \\
\text { Footnote b }\end{array}$ & $\stackrel{4}{(1 / \operatorname{art} r)}$ & $\begin{array}{l}2.0 \mathrm{E}-15 \\
\text { and } \\
1.9 \mathrm{E}-14\end{array}$ & 14 & 65 \\
\hline
\end{tabular}

a HASQAP (DOE/RL-94-55), Table 11-1 states that duplicate analyses should have $<20 \%$ relative percent difference when the result is $>5$ times the minimum detectable activity.

b Performance evaluation sample/analys is results should meet the minimum acceptability scores specified by the evaluation study.

$c$

MDCs shall be as Low as reasonably attainable, but shall not exceed the values specified in the table. 
WHC-EP-0857-1

Table 2.3

Sample and Analys is Criteria

for the 340 Facility

\begin{tabular}{|c|c|c|c|c|c|c|c|}
\hline \multicolumn{8}{|c|}{340 FACILITY, 340-B-BLDG Stack } \\
\hline \multicolumn{8}{|c|}{ SAMPLE AND ANALYSIS CRITERIA } \\
\hline Sample Size & $\begin{array}{l}\text { Type of } \\
\text { Analysis } \\
\end{array}$ & Precision ${ }^{a}$ & Accuracy & $\begin{array}{r}\text { Samples/yr } \\
\text { (delivery } \\
\text { frequency) }\end{array}$ & $\begin{array}{r}\mathrm{MDC}^{\mathrm{C}}, \\
\mu \mathrm{CI} / \mathrm{CC} \\
\end{array}$ & $\begin{array}{l}\text { TT, } \\
\text { days } \\
\end{array}$ & $\begin{array}{l}\text { Untt } \\
\text { Price, } \\
\end{array}$ \\
\hline $\begin{array}{l}\text { nominal } \\
2 \text { cfm for } \\
\text { period of } \\
\text { collection, } \\
\text { unless } \\
\text { otherwise } \\
\text { indicated }\end{array}$ & $\begin{array}{l}\text { gross } \alpha \\
\text { and } \\
\text { gross } B\end{array}$ & $<20 \%$ & $\begin{array}{c}\text { See } \\
\text { Footnote b }\end{array}$ & $\left(1 / \operatorname{qrtr}^{4}\right)$ & $\begin{array}{l}2.0 \mathrm{E}-15 \\
\text { and } \\
1.9 \mathrm{E}-14\end{array}$ & 14 & 65 \\
\hline
\end{tabular}

a HASQAP (DOE/RL-94-55), Table $11-1$ states that duplicate analyses should have $<20 \%$ relative percent difference when the result is $>5$ times the minimum detectable activity.

b Performance evaluation sample/analysis results should meet the minimum acceptability scores specified by the evaluation study.

MDCs shall be as low as reasonably attainable, but shall not exceed the values specified in the table. 
WHC-EP-0857-1

Table 3.1

Sample and Analysis Criteria

for the FFTF

\begin{tabular}{|c|c|c|c|c|c|c|c|}
\hline \multicolumn{8}{|c|}{ FFTF, FFTF-CB-EX Stack } \\
\hline \multicolumn{8}{|c|}{ SAMPLE AND ANALYSIS CRITERIA } \\
\hline Sample Size & $\begin{array}{l}\text { Type of } \\
\text { Analysis } \\
\end{array}$ & Precision ${ }^{a}$ & Accuracy & $\begin{array}{l}\text { Samples/yr } \\
\text { (delivery } \\
\text { frequency) }\end{array}$ & $\begin{array}{l}\mathrm{MDC} \\
\mu \mathrm{C} 1 / \mathrm{CC}\end{array}$ & $\begin{array}{l}\text { TT, } \\
\text { days }\end{array}$ & $\begin{array}{r}\text { Unit } \\
\text { Price, } \\
\$\end{array}$ \\
\hline \multirow{3}{*}{$\begin{array}{l}\text { nominal } 2 \\
\text { cfm for } \\
\text { period of } \\
\text { collection, } \\
\text { unless } \\
\text { otherwise } \\
\text { indicated }\end{array}$} & $\begin{array}{c}\text { gross } \alpha \\
\text { and } \\
\text { gross } B\end{array}$ & \multirow[t]{3}{*}{$<20 \%$} & \multirow[t]{3}{*}{$\begin{array}{c}\text { See } \\
\text { Footnote b }\end{array}$} & $\begin{array}{c}52 \\
(1 / w k)\end{array}$ & $\begin{array}{l}2.0 \mathrm{E}-15 \\
\text { and } \\
1.9 \mathrm{E}-14 \\
\end{array}$ & 14 & 65 \\
\hline & ${ }^{3} \mathrm{H}$ & & & $4^{*}$ & $1.5 \mathrm{E}-9$ & 60 & 500 \\
\hline & ${ }^{131} 1$ & & & $\left(1 / 2^{26}\right.$ wks $)$ & $2.1 \mathrm{E}-13$ & 14 & 35 \\
\hline
\end{tabular}

* Four samples will be collected during a 4 week period ( 1 sample per week). The samples shall be analyzed as a batch to reduce analytical costs per sample.

a HASQAP (DOE/RL-94-55), Iable 11-1 states that duplicate analyses should have < $20 \%$ relative percent difference when the result is $>5$ times the minimum detectable activity.

b Performance evaluation sample/analysis results should meet the minimum acceptability scores specified by the evaluation study.

C MDCs shall be as low as reasonably attainable, but shall not exceed the values specified in the table.

d Sample frequency may be reduced during the calendar year. A reduction in the sample frequency may result in less samples delivered to PNWL for analysis. 
WHC-EP-0857-1

Table 3.2

Sample and Analysis Criteria

for the FFTF

\begin{tabular}{|c|c|c|c|c|c|c|c|}
\hline \multicolumn{8}{|c|}{ FFTF, FFTF-RE-SB Stack } \\
\hline \multicolumn{8}{|c|}{ SAMPLE AND ANALYSIS CRITERIA } \\
\hline Sample Size & $\begin{array}{l}\text { Type of } \\
\text { Analysis } \\
\end{array}$ & Precision ${ }^{a}$ & Accuracy & $\begin{array}{l}\text { Samples /yr } \\
\text { (del ivery } \\
\text { frequency) }\end{array}$ & $\begin{array}{l}\mathrm{MDC}^{\mathrm{C}}, \\
\mu \mathrm{Ci} / \mathrm{CC}\end{array}$ & $\begin{array}{l}\text { TT, } \\
\text { days }\end{array}$ & $\begin{array}{l}\text { Unit } \\
\text { Price, } \\
\text { S }\end{array}$ \\
\hline \multirow{2}{*}{$\begin{array}{l}\text { nominal } 2 \\
\text { cfm for } \\
\text { period of } \\
\text { collection, } \\
\text { unless } \\
\text { otherwise } \\
\text { indicated }\end{array}$} & $\begin{array}{l}\text { gross } \alpha \\
\text { and } \\
\text { gross } \beta\end{array}$ & \multirow[t]{2}{*}{$<20 \%$} & \multirow[t]{2}{*}{$\begin{array}{c}\text { See } \\
\text { Footnote } b\end{array}$} & $\begin{array}{c}52 \\
(1 / w k)\end{array}$ & $\begin{array}{l}2.0 E-15 \\
\text { and } \\
1.9 E-14\end{array}$ & 14 & 65 \\
\hline & ${ }^{131} \mathrm{I}$ & & & $\frac{26}{(1 / 2 \text { wks })}$ & $2.1 E-13$ & 14 & 35 \\
\hline
\end{tabular}
HASOAP (DOE/RL-94-55), Table 11-1 states that duplicate analyses should have < $20 \%$ relative percent difference when the result is $>5$ times the minimum detectable activity.

b Performance evaluation sample/analysis results should meet the minimm acceptability scores specified by the evaluation study.

C MDCs shall be as low as reasonably attainable, but shall not exceed the values specified in the table.

d

Sample frequency may be reduced during the calendar year. A reduction in the sample frequency may result in less samples delivered to PNNL for analys is. 
WHC-EP-0857-1

Table 3.3

Sample and Analysis Criteria

for the FFTF

\begin{tabular}{|c|c|c|c|c|c|c|c|}
\hline \multicolumn{8}{|c|}{ FFTF, FFTF-HT-TR Stack } \\
\hline \multicolumn{8}{|c|}{ SAMPLE AND ANALYSIS CRITERIA } \\
\hline Sample Size & $\begin{array}{l}\text { Type of } \\
\text { Analysis }\end{array}$ & Precision ${ }^{a}$ & Accuracy & $\begin{array}{l}\text { Samples/yr } \\
\text { (delivery } \\
\text { frequency) }\end{array}$ & $\begin{array}{l}M D C^{c} \\
\mu \mathrm{Cl} / \mathrm{CC}\end{array}$ & dT, & $\begin{array}{l}\text { Unit } \\
\text { Price, } \\
\end{array}$ \\
\hline $\begin{array}{l}\text { nominal } \\
2 \text { cfm for } \\
\text { period of } \\
\text { collection, } \\
\text { unless } \\
\text { otherwise } \\
\text { indicated }\end{array}$ & $\begin{array}{c}\text { gross } \alpha \\
\text { and } \\
\text { gross } B\end{array}$ & $<20 \%$ & $\begin{array}{c}\text { See } \\
\text { footnote } b\end{array}$ & $\begin{array}{c}52 \\
(1 / w k)\end{array}$ & $\begin{array}{l}2.0 \mathrm{E}-15 \\
\text { and } \\
1.9 \mathrm{E}-14\end{array}$ & 14 & 65 \\
\hline
\end{tabular}

a HASOAP (DOE/RL-94-55), Table 11-1 states that duplicate analyses should have $<20 \%$ relative percent difference when the result is $>5$ times the minimu detectable activity.

b Performance evaluation sample/analys is results should meet the minimum acceptability scores specified by the evaluation study.

c MDCs shalt be as Low as reasonably attainable, but shall not exceed the values specified in the table.

a Sample frequency may be reduced during the calendar year. A reduction in the sample frequency may result in less samples delivered to PNNL for analysis. 
WHC-EP-0857-1

Table 4.1

Sample and Analysis Criteria

for the 437 Maintenance and Storage Facility (MASF)

\begin{tabular}{|c|c|c|c|c|c|c|c|}
\hline \multicolumn{8}{|c|}{ MASF, 437-MN\&ST Stack } \\
\hline \multicolumn{8}{|c|}{ SAMPLE AND ANALYSIS CRITERIA } \\
\hline Sample Size & $\begin{array}{l}\text { Type of } \\
\text { Analys is }\end{array}$ & Precision & Accuracy & $\begin{array}{l}\text { Samples /yr } \\
\text { (delivery, } \\
\text { frequency) }\end{array}$ & $\begin{array}{l}\mathrm{MDC}^{\mathrm{C}}, \\
\mu \mathrm{C} / \mathrm{CC}\end{array}$ & $\begin{array}{l}\text { TT, } \\
\text { days }\end{array}$ & $\begin{array}{r}\text { Unit } \\
\text { Price, } \\
\$\end{array}$ \\
\hline $\begin{array}{l}\text { nominal } \\
2.0 \text { cfm for } \\
\text { period of } \\
\text { collection, } \\
\text { unless } \\
\text { otherwise } \\
\text { indicated }\end{array}$ & $\begin{array}{c}\operatorname{gross} \alpha \\
\text { and } \\
\text { gross } \beta\end{array}$ & $<20 \%$ & $\begin{array}{c}\text { See } \\
\text { Footnote b }\end{array}$ & $\begin{array}{c}52 \\
(1 / w k)\end{array}$ & $\begin{array}{l}2.0 \mathrm{E}-15 \\
\text { and } \\
1.9 \mathrm{E}-14\end{array}$ & 14 & 65 \\
\hline
\end{tabular}

a HASOAP (DOE/RL-94-55), Table $11-1$ states that duplicate analyses should have $<20 \%$ relative percent difference when the result is $>5$ times the minimum detectable activity.

b Performance evaluation sample/analys is results should meet the minimum acceptability scores specified by the evaluation study.

c MDCs shall be as low as reasonably attainable, but shall not exceed the values specified in the table.

Sample frequency may be reduced during the calendar year. A reduction in the sample frequency may result in less samples delivered to PNNL for analysis. 
WHC-EP-0857-1

Table 4.2

Sample and Analysis Criteria

for the 437 Maintenance and Storage Facility (MASF)

\begin{tabular}{|c|c|c|c|c|c|c|c|}
\hline \multicolumn{8}{|c|}{ MASF, 437-1-61 Stack } \\
\hline \multicolumn{8}{|c|}{ SAMPLE AND ANALYSIS CRITERIA } \\
\hline Sample Size & $\begin{array}{l}\text { Type of } \\
\text { Analys is }\end{array}$ & Precision & Accuracy & $\begin{array}{l}\text { Samples/yr } \\
\text { (delivery } \\
\text { frequency) }\end{array}$ & $\begin{array}{l}M D C^{\mathrm{e}}, \\
\mu \mathrm{CH} / \mathrm{cc}\end{array}$ & $\begin{array}{l}\text { TT, } \\
\text { days }\end{array}$ & $\begin{array}{c}\text { Unit } \\
\text { Price, } \\
\$\end{array}$ \\
\hline $\begin{array}{l}\text { nominal } \\
2 \text { cfm for } \\
\text { period of } \\
\text { collection, } \\
\text { unless } \\
\text { otherwise } \\
\text { indicated }\end{array}$ & $\begin{array}{c}\operatorname{gross} \alpha \\
\text { and } \\
\text { gross } B\end{array}$ & $<20 \%$ & $\begin{array}{c}\text { See } \\
\text { Footnote b }\end{array}$ & 4 & $\begin{array}{l}2.0 \mathrm{E}-15 \\
\text { and } \\
1.9 \mathrm{E}-14\end{array}$ & 14 & 65 \\
\hline
\end{tabular}

a HASQAP (DOE/RL-94-55), Table 11-1 states that duplicate analyses should have < $20 \%$ relative percent difference when the result is $>5$ times the minimum detectable activity.

b Performance evaluation sample/analysis results should meet the minimum acceptability scores specified by the evaluation study.

c MDCs shalt be as low as reasonably attainable, but shall not exceed the values specified in the table. 
WHC-EP-0857-1

Table 5

ERS Reporting Parameters

\begin{tabular}{|c|c|c|c|c|c|}
\hline $\begin{array}{l}\text { EDP } \\
\text { Code }\end{array}$ & $\begin{array}{l}\text { File } \\
\text { Title }\end{array}$ & $\begin{array}{l}\text { Stack code } \\
\text { or } \\
\text { Stream code }\end{array}$ & Companion files & $\begin{array}{l}\text { Harning Level } \\
\text { Factor }\end{array}$ & $\begin{array}{l}\text { Reportable } \\
\text { Radionucl ides }\end{array}$ \\
\hline $\mathrm{FOO2}$ & 340 Vault Tank Exhaust & 340-NT-EX & $\begin{array}{l}\mathrm{F} 602 \\
\mathrm{~F} 017\end{array}$ & 1 & $\begin{array}{l}\text { alpha } \\
\text { beta }\end{array}$ \\
\hline F003 & 306 Facility & $306 \mathrm{E}-\mathrm{ULAB}$ & none & 1 & $\begin{array}{l}\text { alpha } \\
\text { beta }\end{array}$ \\
\hline F008 & 340 B Building & $340-B-B L D$ & none & 1 & $\begin{array}{l}\text { alpha } \\
\text { beta }\end{array}$ \\
\hline F009 & $\begin{array}{c}340 \text { Decontamination } \\
\text { Facility }\end{array}$ & $340-D E C O N$ & none & 1 & $\begin{array}{l}\text { alpha } \\
\text { beta }\end{array}$ \\
\hline Fol1 & FFTF Combined Exhaust & FFTF-CB-E & $\begin{array}{l}\text { F018 } \\
\text { F024 }\end{array}$ & 1 & $\begin{array}{l}\text { alpha } \\
\text { beta }\end{array}$ \\
\hline F012 & $\begin{array}{l}\text { FFTF Lower Reactor } \\
\text { Service Building }\end{array}$ & FFTF-RESB & F016 & 1 & $\begin{array}{c}\text { alpha } \\
\text { beta }\end{array}$ \\
\hline $\mathrm{F} 013$ & $\begin{array}{l}\text { FFTF Reactor Heat } \\
\text { Transport System }\end{array}$ & FFTF-HT-T & none & 1 & $\begin{array}{l}\text { alpha } \\
\text { beta }\end{array}$ \\
\hline F014 & $\begin{array}{c}\text { MASF } \\
437-M N \& S T\end{array}$ & 437-MN\&ST & none & 1 & $\begin{array}{l}\text { alpha } \\
\text { beta }\end{array}$ \\
\hline F015 & 309 Facility PTRAEU & 12632 & none & 1 & $\begin{array}{l}\text { alpha } \\
\text { beta }\end{array}$ \\
\hline Fol6 & $\begin{array}{l}\text { FFTF Lower Reactor } \\
\text { Service Building I-13I }\end{array}$ & FFTF-RESB & F012 & 1 & $I-131$ \\
\hline F017 & $\begin{array}{c}340 \text { Vau\}t Tank Exhaust } \\
\text { I-131 Charcoal Cart }\end{array}$ & 340-NT-EX & $\begin{array}{l}\mathrm{F} 002 \\
\mathrm{~F} 602 \\
\end{array}$ & 1 & $I-131$ \\
\hline F018 & $\begin{array}{r}\text { FFTF Combined Exhaust } \\
1-131\end{array}$ & FFTF-CB-E & $\begin{array}{l}F 011 \\
F 024 \\
\end{array}$ & 1 & $1-131$ \\
\hline Fo19 & $\begin{array}{c}\text { MASF } \\
437-1-61 \\
\end{array}$ & $437-1-61$ & none & 1 & $\begin{array}{l}\text { alpha } \\
\text { beta }\end{array}$ \\
\hline F602 & $\begin{array}{l}340 \text { Vault Tank Exhaust } \\
\text { Quarterly, Composite }\end{array}$ & 340-NT-EX & $\begin{array}{l}\text { F002 } \\
\text { F017 }\end{array}$ & 1 & $\begin{array}{c}\mathrm{Pu}-238 \\
\mathrm{Pu}-239,240 \\
\mathrm{Pu}-242 \\
\mathrm{Am}-241 \\
\mathrm{Cs}-137\end{array}$ \\
\hline F024 & $\begin{array}{l}\text { FFTF Combined Exhaust } \\
\mathrm{H}-3\end{array}$ & FFTF-CB-E & $\begin{array}{l}\text { F011 } \\
\text { F018 }\end{array}$ & 1 & $H-3$ \\
\hline
\end{tabular}


WHC-EP-0857-1

\subsection{GLOSSARY}

ABBREVIATIONS, ACRONYMS, AND INITIALISMS

$\begin{array}{ll}\text { RL } & \text { U.S. Department of Energy, Richland Operations office } \\ \text { EIS/ODIS } & \begin{array}{l}\text { Effluent Information System/Onsite Discharge } \\ \text { Information System }\end{array} \\ \text { EPA } & \text { Environmental Protection Agency } \\ \text { US } & \text { United States } \\ \text { MDC } & \text { minimum detectable concentrations } \\ \text { TT } & \text { turnaround time } \\ \text { AWS } & \text { Air and Water Services } \\ \text { PNNL } & \text { Pacific Northwest National Laboratory } \\ \text { SOW } & \text { Statement of Work } \\ \text { CFR } & \text { Code of Federal Regulations } \\ \text { WHC } & \text { Westinghouse Hanford Company } \\ \text { INEL } & \text { Idaho National Engineering Laboratory } \\ \text { QA } & \text { Quality Assurance } \\ \text { Cfm } & \text { cubic feet per minute }\end{array}$


WHC-EP-0857-1

\subsection{DEFINITIONS}

Turnaround Time - Elapsed time, in days, from when a sample is received by the laboratory until the analysis is reported to AWS. 
WHC-EP-0857-1

DISTRIBUTION

ONSITE

30

Westinghouse Hanford Company
P. S. Barajas
T7-37
L. D. Berneski
L6-04
E. J. Bitten
N1-41
N. R. Dahl
N2-57
W. E. Davis
H6-20
L. P. Diediker
S3-95
T. A. Dillhoff
N2-57
J. N. Diven
H8-20
D. R. Ekstrom
16-52
B. G. Erlandson
H6-20
D. G. Farwick
B. P. Fisher
T6-03
B. P. Gleckler
L6-39
E. M. Greager
S3-95
K. J. Hagerty
H6-20
D. L. Halgren
L6-04
J. A. Hunter
L6-04
J. M. Kisielnicki
L5-31
J. J. Luke
L6-39
D. G. Panther
H6-25
J. K. Perry
L6-39
D. E. Rasmussen
H6-20
L. W. Roberts
N1-47
R. W. Szelmeczka
L6-04
E. R. Wood
L6-05
L5-3]
L. W. Vance
B1-13
Central Files
A3-88
DPC
A3- 94

Pacific Northwest National Laboratory
T. L. Almeida
P7-25
0. P. Bredt
P7-27
L. R. Greenwood
P7 -22
K. J. Kuhl-K1 inger
P7 -27
J. M. Latkovich
P7-27
R. G. Swoboda
P7-22
K. K. Thomas
P7-22 